\title{
Migranci czy uchodźcy? Prawne aspekty ochrony osób migrujących ze względu na negatywne zmiany środowiska naturalnego
}

\begin{abstract}
Migrants or refugees? Legal aspects of protecting people migrating due to adverse effects of environmental change: The article provides a general overview of the issue of environmentally induced migration. Despite having been a topic of climate change debate for over 30 years and a growing concern of the international community, environmentally displaced persons are not defined or described in any legally binding document. The first part of the article investigates difficulties with providing a definition of environmental migrants. Next, it examines different projects of international regulations and approaches. In the final section the author analyses the key issues of environmentally induced migration, namely: environmental factors, including slow and sudden onset events, characteristics of the movement, with focus on forced and cross-border migration and the appropriate terminology (migrant or refugee).
\end{abstract}

Słowa kluczowe: $\quad$ zmiany klimatu, migracje klimatyczne, uchodźcy klimatyczni, przesiedleńcy środowiskowi

Keywords: climate change, environmentally induced migration, climate refugees, environmentally displaced persons

* Specjalista ds. międzynarodowych w BAS, doktorantka na Wydziale Prawa i Administracji Uniwersytetu Warmińsko-Mazurskiego •

e-mail: kamila.groszkowska@sejm.gov.pl • https://orcid.org/oooo-ooo2-8618-1302

\section{Wstęp}

Globalne ocieplenie i zmiany klimatu mają istotny wpływ na życie milionów ludzi na całym świecie. W debacie międzynarodowej na temat konsekwencji zmieniających się warunków środowiska naturalnego i klimatu coraz częściej poruszana jest kwestia migracji. Po raz pierwszy pojęcie „uchodźców klimatycznych” zostało użyte w latach 80. ubiegłego wieku jako określenie osób zmuszonych do opuszczenia swojego naturalnego miejsca zamieszkania ze względu na takie zmiany środowiska naturalnego, które doprowadziłyby do zagrożenia 
ich życia lub zdrowia. Do dnia dzisiejszego, ponad 30 lat od pojawienia się tej problematyki w literaturze naukowej, nie została ustalona powszechnie obowiązująca definicja grupy ludzi zmuszonych do migracji ze względu na czynniki związane ze zmianami środowiska i klimatu.

Problematyka wpływu zmian klimatu na zjawisko migracji została poruszona przez naukowców z Międzyrządowego Zespołu ds. Zmian Klimatu (Intergovernmental Panel on Climate Change; dalej: IPCC), działającego w ramach Organizacji Narodów Zjednoczonych. W opublikowanym w 2007 r. raporcie analitycznym ${ }^{1}$ stwierdzono, że zgodnie z przewidywaniami zmiany klimatu będą postępować coraz szybciej, w konsekwencji czego wzrastająca liczba osób na całym świecie będzie narażona na ekstremalne zjawiska pogodowe, podnoszenie się poziomu mórz i oceanów i inne zagrożenia klimatyczne, które doprowadzą do zdecydowanego wzrostu migracji. Wpływ czynników środowiskowych na mobilność ludzi jest zjawiskiem złożonym, często występującym w związku z czynnikami społecznymi, ekonomicznymi i politycznymi. Z tego względu trudno jest precyzyjnie określić grupę poszkodowanych przez klimat i oszacować liczbę zmuszonych do opuszczenia swojego miejsca zamieszkania z powodu stanu środowiska, niepozwalającego na normalne funkcjonowanie. Wśród uczestników debaty brakuje porozumienia zarówno co do kryteriów, jakie należałoby przyjąć do ustalenia definicji osób migrujących z tego powodu, jak również co do samej zasadności jej formułowania i wyodrębniania ich jako grupy wymagającej szczególnej ochrony. Brak konsensusu i powszechnie obowiązującej terminologii doprowadziły do dużego pluralizmu pojęciowego. W tekstach naukowych, prawnych i politycznych stosowane są takie pojęcia jak: uchodźcy klimatyczni (climate change refugees), uchodźcy środowiskowi (environmental refugees), migranci klimatyczni (climate change migrants), migranci środowiskowi (environmental migrants), przesiedleńcy klimatyczni (climate change displaced persons), przesiedleńcy środowiskowi (environmentally displaced persons). W niniejszym artykule pojęcie migranci klimatyczni jest używane dla określenia osób decydujących się na przemieszczenie w sposób dobrowolny, ze względu na negatywne zmiany środowiska naturalnego lub klimatu, natomiast pojęcie przesiedleńcy klimatyczni dla określenia grupy osób zmuszonych do przemieszczenia się ze względu na te zmiany. Ogólne zjawisko mobilności ludzi z powodu szeroko rozumianych czynników środowiskowych określane jest jako migracje klimatyczne.

Wykazanie zależności między decyzją o opuszczeniu miejsca zamieszkania a czynnikiem środowiskowym jest trudne i uzależnione od jego rodzaju. Za dużą

1 Intergovernmental Panel on Climate Change, Summary for Policymakers [w:] Climate Change 2007: Impacts, Adaptation and Vulnerability. Contribution of Working Group II to the Fourth Assessment Report of the Intergovernmental Panel on Climate Change, M.L. Parry, O.F. Canziani, J.P. Palutikof, P.J. van der Linden and C.E. Hanson eds., Cambridge University Press, 2007. 
część migracji odpowiedzialne są różnego rodzaju katastrofy, np. huragany, burze, powodzie, czyli zdarzenia o nagłym początku. Zgodnie ze statystykami Programu Narodów Zjednoczonych ds. Rozwoju co roku w wyniku takich zdarzeń przesiedlanych jest średnio $21 \mathrm{mln}$ ludzi ${ }^{2}$. Trudniejsze do oszacowania są liczby osób migrujących lub przesiedlających się ze względu na zdarzenia długotrwałe, o powolnym początku, takie jak susze, pustynnienie, zwiększanie poziomu zasolenia, zakwaszanie oceanów, podnoszenie się poziomu wód. Jedne z pierwszych analiz z lat 80. i 90. ubiegłego wieku przewidywały, że liczba migrantów i przesiedleńców klimatycznych wyniesie 25-30 mln rocznie ${ }^{3}$. Szeroko komentowany raport Sterna ${ }^{4}$ zasugerował, że do roku 2050 ponad 200 mln ludzi stanie się ofiarami zmian klimatycznych, co w poważny sposób zwiększy migracje ${ }^{5}$. Rok później organizacja Christian Aid ogłosiła, że liczba przemieszczających się ze względu na warunki klimatyczne może w 2050 r. wynieść aż miliard ${ }^{6}$. Obecnie przewidywania te uznane są za mało wiarygodne, przede wszystkim ze względu na problemy w zebraniu danych i określeniu, które migracje można zakwalifikować jako „klimatyczne”. Jednakże nawet jeżeli migracje klimatyczne stanowiłyby tylko niewielki procent wszystkich migrujących (w 2015 r. liczba migrantów transgranicznych i wewnętrznych wynosiła odpowiednio 244 i $740 \mathrm{mln}^{8}$ ), to wciąż mamy do czynienia z grupą milionów ludzi o nieuregulowanym statusie i pozbawionych ochrony prawnej. Problem ten został dostrzeżony przez ONZ, która w drodze negocjacji międzyrządowych przyjęła na Zgromadzeniu Ogólnym 19 grudnia 2018 r. rezolucję w sprawie globalnego programu bezpiecznej i regularnej migracji (Global Compact for Safe, Orderly and Regular Migration ${ }^{9}$ ). Global Compact zawiera 23 cele ogólne, z czego cel drugi - „Minimalizowanie

2 S. Opitz Stapleton, R. Nadin, Ch. Watson, J. Kellett, Climate change, Migration and Displacement: the need for a risk-informed and coherent approach, United Nations Development Programme, 2017, s. 9.

3 Zob. E. El-Hinnawi, Environmental Refugees, United Nations Environment Programme, Hertfordshire, 1985; N. Myers, J. Kent, Environmental Exodus: An Emergent Crisis in the Global Arena, Climate Institute, Washington D.C., 1995.

${ }^{4}$ Raport Sterna, właściwie Przegląd Sterna nt. ekonomiki zmian klimatycznych, to 700-stronicowy raport opublikowany 30 października 2006 r. przez ekonomistę Nicholasa Sterna, przygotowany dla rządu Zjednoczonego Królestwa, który omawia wpływ zmian klimatycznych i globalnego ocieplenia na światową gospodarkę.

5 Zob. S. Opitz Stapleton, R. Nadin, Ch. Watson, J. Kellett, Climate change, op. cit., s. 10.

${ }^{6}$ Ibidem.

7 Ibidem.

8 Zob. United Nations Department of Economic and Social Affairs, International Migration Report 2015. Highlights, 2016, ST/ESA/SER.A/375, s. 5.

${ }^{9}$ United Nations General Assembly, Global Compact for Safe, Orderly and Regular Migration, 2019, A/RES/73/195. Global Compact jest niewiążącym dokumentem, przyjętym w drodze negocjacji międzyrządowych, przygotowanym pod auspicjami ONZ, obejmującym wszystkie wymiary migracji międzynarodowych. 
niekorzystnych czynników przyczyniających się do opuszczania swojego miejsca zamieszkania" - dotyczy w szczególny sposób migracji ze względu na katastrofy naturalne, negatywne skutki zmian klimatu oraz degradację środowiska.

Celem niniejszego opracowania jest opisanie problematyki migracji klimatycznych, ze szczególnym uwzględnieniem kwestii związanych z brakiem powszechnie obowiązującej definicji zjawiska, trudności w wypracowaniu wspólnego stanowiska $\mathrm{w}$ środowisku naukowym i prawnym, zarówno w zakresie definicji osób przemieszczających się ze względu na czynniki środowiskowe, jak i proponowanych środków ochrony prawnej. Artykuł analizuje zjawisko migracji klimatycznych na podstawie trzech kryteriów: rodzaj czynników środowiskowych, które je wywołują, charakter migracji oraz możliwości przyznania ochrony prawnej wynikającej z prawa uchodźczego.

\section{Trudności w opracowaniu definicji}

Podstawowym problemem w zakresie analizowania migracji klimatycznych jest brak powszechnie obowiązującej definicji zjawiska, jak również brak zgody w środowisku naukowym i prawnym co do zakresu przedmiotowego tego pojęcia. Zdecydowana większość badaczy zwraca uwagę na złożoność zjawiska migracji i trudności w wyodrębnieniu czynników środowiskowych jako podstawowej przyczyny ${ }^{10}$, obok kwestii ekonomicznych, politycznych, społecznych czy demograficznych. Co więcej, często między tymi czynnikami występuje skomplikowania sieć powiązań przyczynowo-skutkowych, np. w sytuacji, kiedy ubóstwo lub trudności ekonomiczne motywujące do wyjazdu są bezpośrednią konsekwencją zmian klimatu ${ }^{11}$. Niektóre opracowania naukowe pomijają kwestie definicyjne, opierając się na ogólnych założeniach zjawiska migracji klimatycznych, jednakże większość z nich podejmuje próby uzasadnienia terminologii, jaką się posługuje, sformułowania własnej, czasem mocno skomplikowanej lub mało precyzyjnej, definicji ${ }^{12}$.

Po raz pierwszy pojęcia „uchodźca środowiskowy” użył w 1985 r. badacz Organizacji Narodów Zjednoczonych Essam El-Hinnawi. W dokumencie

${ }_{10}$ Zob. m.in. F. Gemenne, One good reason to speak of climate refugees, „Forced Migration Review" 2015, Vol. 49; E. Ferris, J. Bergmann, Soft law, migration and climate change governance, "Journal of Human Rights and the Environment" 2017, Vol. 8, No. 1, https:// doi.org/10.4337/jhre.2017.01.07; B. Mayer, Concept of Climate Migration Advocacy and its Prospects, Edward Elgar Publishing, Cheltenham 2016.

11 P. Krajewski, K. Groszkowska, Problematyka migracji klimatycznych w polityce i prawie międzynarodowym, „Journal of Modern Science” 2018, Vol. 1, No. 36, s. 148, https://doi. org/10.13166/jms/85114.

${ }^{12}$ F. Biermann, I. Boas, Preparing for w warmer world: towards a global governance system to protect climate refugees, „Global Environmental Politics” 2010, Vol. 10, No. 1, s. 63, https:// doi.org/10.1162/glep.2010.10.1.60. 
przygotowanym dla Programu Środowiskowego ONZ El-Hinnawi nazwał uchodźcami środowiskowymi ludzi, którzy zostali zmuszeni do tymczasowego lub stałego opuszczenia swojego miejsca zamieszkania ze względu na (naturalne lub wywołane przez człowieka) negatywne zmiany środowiska naturalnego, jeżeli te zmiany doprowadziłyby do zagrożenia ich życia lub poważnego obniżenia jego jakości ${ }^{13}$. Przez negatywne zmiany środowiska El-Hinnawi rozumiał jakiekolwiek fizyczne, chemiczne lub biologiczne zmiany w ekosystemie, które, w konsekwencji, stale lub tymczasowo nie mogłyby zapewnić człowiekowi możliwości do życia. Zaproponowana przez niego definicja wyróżniała trzy kategorie uchodźców środowiskowych. Grupa pierwsza obejmowała ludzi tymczasowo zmuszonych do opuszczenia swojego miejsca zamieszkania ze względu na katastrofę naturalną (np. trzęsienie ziemi lub huragan), z zamiarem powrotu, kiedy usunięte zostaną jej następstwa. Grupa druga dotyczyła uchodźców przesiedlonych na stałe, ze względu na trwałe zmiany środowiska, spowodowane najczęściej działalnością człowieka. Trzecia grupa obejmowała wszystkich innych uchodźców środowiskowych, którzy zdecydowali się na migrację stałą lub tymczasową w celu poszukiwania lepszych warunków życia, ze względu na postępującą i nieodwracalną degradację środowiska naturalnego. Definicja zaproponowana przez El-Hinnawiego, jakkolwiek szeroka i mało precyzyjna, stała się punktem wyjścia dla późniejszych badaczy. W 1995 r. Norman Myers posłużył się tym pojęciem dla opisania osób, które nie mogą już prowadzić bezpiecznego życia na zamieszkiwanych przez siebie terenach, ze względu na czynniki środowiskowe o nietypowym natężeniu, przede wszystkim susze, pustynnienie, wylesianie, erozję gleby, utrudniony dostęp do wody, zmiany klimatu, jak również katastrofy naturalne, takie jak burze, cyklony i powodzie ${ }^{14}$.

W debacie na temat zjawiska migracji klimatycznych dokonał się podział na dwie grupy. Pierwszą stanowią przedstawiciele nurtu alarmistycznego, podkreślający zagrożenia dla praw człowieka wynikające ze zmian klimatu oraz konieczność objęcia ochroną ludzi wysiedlonych na skutek czynników środowiskowych, najlepiej w drodze międzynarodowych regulacji prawnych. Do drugiej grupy należą sceptycy, którzy krytycznie odnoszą się do potrzeby objęcia specjalną ochroną klimatycznych uchodźców, zwracając uwagę na trudności z ich zdefiniowaniem, i, przede wszystkim, odróżnieniem od tzw. migrantów ekonomicznych. Podział w środowisku naukowym na alarmistów i sceptyków ma bezpośrednie przełożenie na podejście prawodawców i twórców polityk do definiowania grupy wymagającej ochrony prawnej i propozycji adekwatnych środków ochrony.

13 E. El-Hinnawi, Environmental, op. cit.

${ }^{14}$ N. Myers, J. Kent, Environmental, op. cit., s. 17. 
Dla przedstawicieli nurtu alarmistycznego najbardziej optymalną formą ochrony prawnej jest nowa konwencja międzynarodowa dotycząca migracji klimatycznych, która zawierałaby powszechnie obowiązującą definicję zjawiska. Badacze próbujący rozwinąć definicje zaproponowane przez El-Hinnawiego oraz Myersa zwracają uwagę na trzy obszary wymagające precyzyjnego określenia: a) przyczyna migracji, tj. rodzaj czynnika klimatycznego, który ją wywołał; b) charakter migracji; c) uzasadnienie używanych pojęć migranta lub uchodźcy ${ }^{15}$.W dalszej części artykułu zostaną zaprezentowane cztery definicje przygotowane na potrzeby bardziej współczesnych projektów regulacji międzynarodowych, które, mimo iż dotyczą tego samego zjawiska, różnią się na poziomie każdego z tych trzech obszarów.

\section{Przykłady definicji w projektach konwencji międzynarodowych}

Pierwszym $z$ analizowanych projektów jest Ramowa konwencja o międzynarodowym statusie przesiedleńców środowiskowych ${ }^{16}$, opracowana przez zespół francuskiego profesora Michela Prieura. Definiuje ona przesiedleńców środowiskowych (environmentally displaced persons) jako osoby, rodziny i populacje, które ze względu na nagłą lub stopniową katastrofę naturalną, mającą nieunikniony wpływ na ich warunki życia, zmuszone są do opuszczenia swojego miejsca zamieszkania i przesiedlenia lub relokacji. Konwencja nie przewiduje zastrzeżeń i ograniczeń w zakresie czynników środowiskowych, podkreślając, że przyczyna zjawiska nie powinna determinować możliwości jej zastosowania. Przewidzianej w niej ochronie podlegać miały osoby przesiedlone w wyniku nagłych katastrof naturalnych i tych wywołanych przez człowieka, jak również w wyniku powolnego niszczenia środowiska naturalnego, spowodowanego siłami natury lub działalnością człowieka. Autorzy konwencji nie dokonali rozróżnienia ze względu na charakter migracji. $\mathrm{W}$ ich założeniu miał być to dokument uniwersalny, możliwy do zastosowania w jak największej liczbie przypadków. Zastosowanie w konwencji terminu „przesiedleńcy środowiskowi” miało podkreślić nieadekwatność używania w tym kontekście terminologii przewidzianej w prawie uchodźczym i potrzebę uchwalenia nowych standardów ochrony dla osób, które nie spełniają kryteriów przewidzianych w konwencji genewskiej dotyczącej statusu uchodźców ${ }^{17}$.

Potrzebę opracowania konwencji międzynarodowej dostrzegli także australijscy badacze David Hodgkinson i Tess Burton. Opublikowali oni projekt

15 F. Biermann, I. Boas, Preparing, op. cit., s. 64.

${ }^{16}$ M. Prieur, J. Marguénaud, G. Monediaire et al., Draft convention on the international status of environmentally displaced persons, „Revue Européenne de Droit de l'Environnement” 2008, No. 4.

17 Konwencja dotycząca statusu uchodźców, sporządzona w Genewie 28 lipca 1951 r., Dz.U. 1991, poz. 119, nr 515; dalej: konwencja genewska. 
konwencji o osobach przesiedlonych ze względu na zmiany klimatu ${ }^{18}$. Zgodnie $\mathrm{z}$ treścią projektu osoby przesiedlone ze względu na zmiany klimatu (climate change displaced persons) to grupy i populacje, których miejsce zamieszkania stało się, lub prawdopodobnie stanie się w przyszłości, stale lub czasowo niezdolne do zapewnienia podstawowych warunków egzystencji w konsekwencji zmian klimatu. Autorzy uznali, że czynnikami klimatycznymi mogą być zarówno nagłe, jak i stopniowe negatywne zmiany w środowisku naturalnym, spowodowane działalnością człowieka. Projekt konwencji przewidywał zakres ochrony zarówno w przypadku migracji tymczasowych, jak i permanentnych oraz transgranicznych i wewnętrznych. Kryterium przymusowości również nie było rozpatrywane - autorzy przyjęli domniemanie, że wszystkie migracje objęte zakresem zaproponowanej definicji są przymusowe. Celem przyjęcia terminologii „przesiedleńcy klimatyczni” było podkreślenie powszechności przyznanej ochrony, mającej, inaczej niż w konwencji genewskiej, zastosowanie do grup i całych populacji.

Inne rozwiązanie zaproponowali Frank Biermann i Ingrid Boas, argumentując, że ochrona prawna uchodźców klimatycznych powinna zostać zapewniona w dodatkowym protokole do Ramowej konwencji Narodów Zjednoczonych w sprawie zmian klimatu $\left(\mathrm{UNFCCC}^{19}\right)^{20}$. Protokół miał dotyczyć uchodźców klimatycznych (climate refugees), którzy zostali zdefiniowani jako osoby, zmuszone do opuszczenia swojego miejsca zamieszkania natychmiast lub w niedalekiej przyszłości, ze względu na nagłe lub stopniowe zmiany w środowisku naturalnym, związane z podnoszeniem się poziomu mórz i oceanów, gwałtownymi zjawiskami pogodowymi lub suszą. Autorzy dokonali również kilku zastrzeżeń. Z zakresu definicji wyłączone zostały czynniki klimatyczne, które mają marginalny tylko związek z przymusowymi migracjami, takie jak fale upałów i rozprzestrzeniające się choroby tropikalne. Wyłączenie objęło również migracje w wyniku działań mających na celu walkę z globalnym ociepleniem (np. budowie tam lub plantacji biopaliw), w wyniku zanieczyszczenia środowiska, a także konfliktów zbrojnych o dostęp do wody lub surowców naturalnych. W kwestii charakteru migracji F. Biermann i I. Boas stanęli na stanowisku, że rozróżnienia co do przymusowości, tymczasowości lub transgraniczności nie są ani zasadne, ani potrzebne. Wprowadzanie takich podziałów mogłoby ich zdaniem sztucznie zmniejszyć skalę problemu i stworzyć dysproporcje w zakresie ochrony, wyłączając z niej np. tych, którzy dobrowolnie zdecydują się na relokację. Opisując omawianą grupę, autorzy posłużyli się terminem „uchodźca”.

18 D. Hodgkinson, T. Burton, H. Anderson, L. Young, The Hour When The Ship Comes In: A Convention For Persons Displaced By Climate Change, „Monash University Law Review” 2010, Vol. 36, No. 1, s. 69-120.

19 United Nations Framework Convention on Climate Change: http://unfccc.int/2860. php.

20 F. Biermann, I. Boas, Preparing, op. cit., s. 76. 
Ich zdaniem w większości kultur i religii na świecie termin ten jest silnie związany $\mathrm{z}$ moralnością i zastosowanie go w kontekście migrantów klimatycznych wzmocni przekaz i nada zjawisku odpowiednią rangę.

Bonnie Docherty i Tyler Giannini w opublikowanym w „Harvard Environmental Law Review” projekcie międzynarodowej konwencji dotyczącej uchodźców klimatycznych weszły w polemikę z F. Biermannem i I. Boas, proponując inną definicję tego samego pojęcia (climate refugees) ${ }^{21}$. Opracowana przez nie konwencja określa uchodźców klimatycznych jako osoby, które zmuszone są opuścić swoje miejsce zamieszkania i przesiedlić się tymczasowo lub na stałe poza granice kraju, w wyniku nagłej lub postępującej degradacji środowiska naturalnego, która jest bezpośrednią konsekwencją zmian klimatu. Zakres podmiotowy ochrony został ograniczony tylko do ofiar zmian klimatu. Przyznanie im uprawnień na gruncie prawa międzynarodowego miał uzasadnić fakt, że działalność człowieka i działalność gospodarcza państw przyczyniają się do pogłębiania zmian klimatu, w związku z czym społeczność międzynarodowa jest zobowiązana wziąć odpowiedzialność za ich konsekwencje (zasada „zanieczyszczający płaci”22). Autorki odwołały się do raportu przygotowanego przez IPCC, zgodnie z którym takimi zmianami mogą być: wzrost temperatur, susze, intensywne burze, wzrost poziomu mórz i oceanów ${ }^{23}$. Charakter migracji w projekcie konwencji został określony w sposób zbliżony do zawierającej definicję „uchodźcy” konwencji genewskiej. W konsekwencji, jej zakresem zostały objęte tylko sytuacje migracji transgranicznych i przymusowych, kiedy decyzja o przesiedleniu jest podjęta na skutek zagrożenia życia lub zdrowia i gdzie konieczna jest pomoc humanitarna. Zgodnie z założeniami autorek uchodźcy klimatyczni mają mieć zapewnioną ochronę międzynarodową do momentu uzyskania nowego obywatelstwa, dobrowolnego powrotu do kraju pochodzenia lub odmowy powrotu, o ile warunki klimatyczne na to pozwalają.

Przytoczone przykłady wskazują na rozbieżności i brak spójności w identyfikowaniu kluczowych elementów definicji, w związku z czym wymagają one bardziej szczegółowego omówienia.

${ }^{21}$ B. Docherty, T. Giannini, Confronting a Rising Tide: A Proposal for a Convention on Climate Change Refugees, „Harvard Environmental Law Review” 2009, Vol. 2, No 2, s. 368.

${ }^{22}$ Zasada „zanieczyszczający płaci” (polluter pays principle) jest powszechnie przyjętą zasadą prawa ochrony środowiska, zgodnie z którą podmiot dokonujący zanieczyszczenia lub degradacji środowiska jest zobowiązany ponieść koszty naprawy takich działań. Zasada jest wyrażona m.in. w art. 191(2) Traktatu o funkcjonowaniu Unii Europejskiej.

${ }^{23}$ B. Docherty, T. Giannini, Confronting, op. cit., s. 370. 


\section{Analiza podstawowych elementów definicji osób migrujących ze względu na zmiany środowiska naturalnego i klimatu}

\section{Rodzaje czynników wywołujących migracje}

Pierwszym obszarem, który należy określić, jest przyczyna migracji, tzn. rodzaj czynnika środowiskowego, który je determinuje. Podstawowy podział został zaproponowany przez IPCC $\mathrm{w}$ raporcie z 2014 r. dotyczącym adaptacji do zmian klimatu ${ }^{24}$. Raport wyróżnił dwa rodzaje migracji: a) wywołane gwałtownymi zjawiskami pogodowymi, których częstotliwość ma wzrosnąć w związku z postępującymi zmianami klimatu, oraz b) spowodowane długotrwałymi zmianami środowiska, takimi jak podnoszenie się poziomu mórz i oceanów, które zaleją małe państwa wyspiarskie, zmuszając zamieszkujące je populacje do przesiedlenia się na nowe tereny ${ }^{25}$. Zagadnienie to zostało rozwinięte $\mathrm{w}$ raporcie Wysokiego Komisarza Narodów Zjednoczonych do spraw praw człowieka ${ }^{26}$. Raport przedstawił podział na zdarzenia o nagłym początku (sudden onset events) oraz zdarzenia o powolnym początku (slow onset events). Do grupy pierwszej zostały zaliczone takie katastrofy, jak huragany, burze i powodzie. Zdarzenia o powolnym początku zdefiniowano w jednym z dokumentów specjalistycznych ONZ jako długotrwały i stopniowy proces powolnych zmian środowiska naturalnego, zachodzący na skutek zdarzeń klimatycznych występujących ze zwiększoną intensywnością lub częstotliwością przez okres wielu miesięcy lub lat ${ }^{27}$. Zaliczane są do nich podnoszenie się poziomu mórz i oceanów, wzrost temperatury, zakwaszanie oceanu, cofanie się lodowców, zwiększanie poziomu zasolenia, wylesianie, pustynnienie, degradacja ziemi i utrata bioróżnorodności ${ }^{28}$. Najnowszy dokument ONZ, Global Compact, w części dotyczącej migracji klimatycznych utrzymał podział czynników środowiskowych na zdarzenia o nagłym i powolnym początku².

${ }^{24}$ Intergovernmental Panel On Climate Change, Summary for policymakers [w:] Climate Change 2014: Impacts, Adaptation, and Vulnerability. Part A: Global and Sectoral Aspects. Contribution of Working Group II to the Fifth Assessment Report of the Intergovernmental Panel on Climate Change [C.B. Field, V.R. Barros, D.J. Dokken, K.J. Mach, M.D. Mastrandrea, T.E. Bilir, M. Chatterjee, K.L. Ebi, Y.O. Estrada, R.C. Genova, B. Girma, E.S. Kissel, A.N. Levy, S. MacCracken, P.R. Mastrandrea, and L.L. White ed.], Cambridge University Press, 2014, s. 1-32.

${ }^{25}$ Ibidem.

26 United Nations High Commissioner for Human Rights, The Slow onset effects of climate change and human rights protection for cross-border migrants, Human Rights Council, 2018, A/HRC/37/CRP.4, $\$ 5$.

27 United Nations Framework Convention on Climate Change, Slow Onset Events - Technical Paper, 2012, FCCC/TP/2012/7, \$20.

28 United Nations High Commissioner for Human Rights, The Slow, op. cit., $₫ 13$.

29 United Nations General Assembly, Global Compac, op. cit., $\$ 18$ (i). 
Żadna z omówionych wyżej definicji nie różnicuje poziomu ochrony osób przesiedlonych ze względu na gwałtowne lub powolne zdarzenia klimatyczne. Już pierwsza definicja uchodźców środowiskowych przedstawiona przez El-Hinnawiego dotyczyła obydwu rodzajów czynników. Tymczasem Biuro Wysokiego Komisarza Narodów Zjednoczonych do spraw praw człowieka wskazuje, że gwałtowne i powolne zdarzenia klimatyczne najczęściej mają różne konsekwencje dla dotkniętych nimi społeczności ${ }^{30}$, co, może przełożyć się na potrzebę zróżnicowania poziomu ochrony międzynarodowej. Raport podkreśla, że zdarzenia powolne skutkują najczęściej migracjami permanentnymi i przymusowymi, zwiększając ryzyko naruszeń podstawowych praw człowieka wysiedlonych osób ${ }^{31}$. Ponadto, takie osoby często nie mogą liczyć na pomoc humanitarną, organizowaną w przypadku wystąpienia katastrofy naturalnej lub innego nagłego zdarzenia klimatycznego.

Drugim aspektem, na który zwracają uwagę autorzy omawianych definicji, jest przyczyna występowania zdarzeń klimatycznych. Niektóre definicje (D. Hodgkinson i T. Burton, B. Docherty i T. Giannini) ograniczają zakres przedmiotowy tylko do zjawisk wynikających bezpośrednio ze zmian klimatu, które z dużym prawdopodobieństwem wystąpiły w konsekwencji działalności człowieka, podczas gdy inne (E. El-Hinnawi, M. Prieur) obejmują wszystkie zjawiska środowiskowe, zarówno naturalne, jak i spowodowane przez człowieka. Powyższe rozbieżności mają duże znaczenie i powodują dodatkowe trudności definicyjne, w szczególności w przypadku przyczyny zdarzeń gwałtownych, jak np. burze, huragany czy powodzie. Przyjmując założenie, że definiowanie zjawiska migracji klimatycznych powinno się ograniczyć tylko do konsekwencji zmian klimatu wywołanych przez człowieka pojawiają się dwa zasadnicze pytania. Po pierwsze, w jaki sposób określić, czy dane zdarzenie wynika ze zmian klimatu czy jest występującym na danym obszarze naturalnym zjawiskiem pogodowym? Po drugie, w jaki sposób udowodnić, że przyczyną zmian klimatu, które wywołały konkretne zdarzenie, jest działalność człowieka, a nie procesy zachodzące w środowisku? Czy możliwe jest przyjęcie założenia, że wszystkie gwałtowne zjawiska pogodowe są konsekwencją zmian klimatu spowodowanych działalnością człowieka? Biorąc pod uwagę, że przywołane definicje wynikają z projektów konwencji międzynarodowych, które, w zamyśle autorów, miały być wiążącymi dokumentami prawnymi, niezbędne jest, aby zawierały one jasne kryteria uznawania zjawiska stanowiącego przyczynę migracji za konsekwencję zmian klimatycznych. Zwolennicy twardego instrumentu prawnego stoją przed koniecznością precyzyjnego określenia tych zależności, co na obecnym etapie rozwoju nauki nie jest proste.

${ }^{30}$ United Nations High Commissioner for Human Rights, The Slow, op. cit., § 17-18.

31 Ibidem, $\$ 21$. 


\section{Charakter migracji klimatycznych}

Kolejnym kluczowym elementem jest charakter migracji, który można określić na podstawie dwóch głównych kryteriów: przymusowości i transgraniczności.

\section{Kryterium przymusu}

Przymusowość decyzji o migracji jest jednym z ważniejszych czynników w zakresie przyznania ochrony międzynarodowej. Jest również podstawowym warunkiem uzyskania statusu uchodźcy na mocy obowiązujących przepisów międzynarodowych. W przypadku migracji klimatycznych wykazanie tej przymusowości może być trudne, szczególnie w zakresie zdarzeń o powolnym początku. Dwie z czterech omówionych definicji podkreślają element przymusowości, posługując się jednak różnymi argumentami. B. Docherty i T. Giannini odwołują się do definicji „uchodźcy” wynikającej z prawa międzynarodowego. Wskazują, że jest ona powszechnie obowiązująca i ukształtowana prawnie, w związku z czym nie należy formułować nowych definicji, ale wykorzystać istniejące już konstrukcje prawne i zaadaptować do szczególnych warunków zmian klimatu ${ }^{32}$. Ich projekt nie zawiera jednakże kryteriów determinowania tej przymusowości, ograniczając się do stwierdzenia, że zakres podmiotowy konwencji powinien zostać zawężony do sytuacji, kiedy niezbędna jest pomoc humanitarna ${ }^{33}$.

D. Hodgkinson i T. Burton nie kwestionują konieczności zastosowania w definicji warunku przymusowości, jednakże ich zdaniem opracowanie takich kryteriów, pozwalających na odróżnienie migrantów klimatycznych od migrantów ekonomicznych, jest przedsięwzięciem zbyt ambitnym ${ }^{34}$. Autorzy stawiają retoryczne pytanie: jak wyznaczyć moment, w którym dana osoba nie realizuje już swojej woli do opuszczenia miejsca zamieszkania, ale jest do tego zmuszona ze względu na warunki środowiska ${ }^{35}$. Proponują rozwiązanie kompromisowe - przyjęcie domniemania, że wszystkie migracje ze względu na takie zmiany klimatu, które mogą w przyszłości doprowadzić do uznania danego terenu za niemożliwy do zamieszkania, są przymusowe.

W literaturze przedmiotu opisane są także koncepcje zastosowania przymusowości jako kryterium rozróżniającego poszczególne podgrupy osób migrujących ze względu na negatywne zmiany środowiska. Fabrice Renaud zaproponował podział na: migrantów motywowanych czynnikami środowiskowymi (environmentally motivated migrants), migrantów przymuszonych czynnikami środowiskowymi (environmentally forced migrants) oraz uchodźców środowi-

32 B. Docherty, T. Giannini, Confronting, op. cit., s. 363.

3 Ibidem, s. 369.

${ }^{34}$ D. Hodgkinson, T. Burton, H. Anderson, L. Young, The Hour, op. cit., s. 89.

${ }^{35}$ Ibidem. 
skowych (environmental refugees) ${ }^{36}$. Migranci motywowani czynnikami środowiskowymi zostali scharakteryzowani jako grupa, która może dobrowolnie podjąć decyzję o migracji, ze względu na postępujące niszczenie środowiska, w celu uniknięcia przewidywanych negatywnych konsekwencji. Powolność tego procesu miałaby dać im wystarczająco dużo czasu, by przygotować się na zmiany. Jako przykłady podane zostały migracje z dawnych terenów przemysłowych i obszarów górniczych, przenoszenie się ludzi z obszarów wiejskich do miast lub migracje w wyniku długotrwałych okresów suszy. Migranci przymuszeni czynnikami środowiskowymi, w przeciwieństwie do grupy pierwszej, są zmuszeni podjąć decyzję o przesiedleniu w celu uniknięcia negatywnych, zaistniałych już zdarzeń, takich jak podnoszenie się poziomu mórz i oceanów czy pustynnienie. Trzecia grupa, tj. uchodźcy środowiskowi, obejmowała tych, którzy uciekaja przed negatywnymi konsekwencjami zdarzeń, takich jak powodzie, rozległe susze i huragany.

Zaproponowany przez F. Renauda podział jest mało przejrzysty i trudno zrozumieć różnice między poszczególnymi grupami. Autor odwołuje się do czynników klimatycznych, które mają warunkować przymusowość migracji, jednakże porównywalne zjawiska o powolnym początku mogą zakwalifikować poszczególne grupy lub osoby zarówno do migrantów przymusowych (pustynnienie), jak i uchodźców (rozległe susze). Nie udziela on tym samym odpowiedzi na przywołane wyżej pytanie o cienką granicę między migracją dobrowolną a przymusową. Warto $\mathrm{w}$ tym kontekście zastanowić się nad podejściem niewprowadzania rozróżnienia ze względu na przymusowość, przyjętym przez pozostałych cytowanych badaczy (M. Prieur, F. Biermann, I. Boas). Wyłączenie z debaty grup migrantów, którzy nie spełniają niejednoznacznego kryterium przymusowości, mogłoby w sposób sztuczny zmniejszyć skalę problemu i doprowadzić do znacznych i trudnych do uzasadnienia na gruncie prawa, polityki lub etyki różnic ochrony prawnej ${ }^{37}$.

\section{Kryterium transgraniczności}

Transgraniczność jest kryterium najbardziej precyzyjnym i budzącym najmniej wątpliwości co do możliwości jego zastosowania. Osoby migrujące w związku z negatywnymi zmianami środowiska mogą albo pozostawać na terenie własnego państwa (migracje wewnętrze) albo przekroczyć granicę i osiedlić się na terytorium innego państwa (migracje transgraniczne). W debacie na temat międzynarodowych standardów ochrony czynnik transgraniczności jest kluczowy. Wśród argumentów na rzecz nieróżnicowania poziomu ochrony ze względu na

${ }^{36}$ F. Renaud et al., Control, Adapt or Flee: How to Face Environmental Migration, „Intersections Publication Series of United Nations University Institute for Environment and Human Security” 2007, No 5, s. 29-31.

37 Por. F. Biermann, I. Boas, Preparing, op. cit., s. 65. 
to kryterium wskazywane są: potrzeba definicji uniwersalnej, obejmującej różnego rodzaju wysiedlenia, jak również odpowiedzialność społeczności międzynarodowej za zmiany klimatu, która powinna przełożyć się na przyjęcie jednolitych standardów ochrony niezależnie od kierunku migracji ${ }^{38} . \mathrm{Z}$ drugiej strony większość migracji, szczególnie tych $\mathrm{w}$ wyniku zdarzeń klimatu o powolnym początku, ma charakter wewnętrzny ${ }^{39}$, w związku z czym osoby przemieszczające się na terenie swojego państwa podlegają prawu krajowemu. Międzynarodowa konwencja, która ingerowałaby bezpośrednio w porząadki prawne i tym samym w suwerenność państw stron, mogłaby wzbudzać wiele wątpliwości. Co więcej, problem tzw. przesiedlonych wewnętrznie był już analizowany przez ONZ. Ze względu na fakt, że takie migracje należą do problemów wewnętrznych danego $\mathrm{kraju}^{40}$, nie została w tym zakresie uchwalona konwencja ani rezolucja Rady Bezpieczeństwa ONZ. Standardy ochrony określono w opracowanych przez specjalnego przedstawiciela Sekretarza Generalnego OZN wytycznych w sprawie przepływów wewnętrznych (Guiding Principles on Internal Displacement ${ }^{41}$ ), mających charakter niewiążącego instrumentu prawnego. Za przesiedlonych wewnętrznie ONZ uznało osoby lub grupy zmuszone do opuszczenia swoich miejsc przebywania w celu uniknięcia konsekwencji między innymi katastrof naturalnych lub powstałych w wyniku działalności ludzi ${ }^{42}$. Zgodnie z określoną w wytycznych zasadą $\mathrm{nr} 3$ odpowiedzialność za przesiedlonych wewnętrznie spoczywa na właściwych organach administracji krajowej, które mają obowiązek zapewnić poszkodowanym ochronę i udzielić im pomocy humanitarnej. Wytyczne nie odnoszą się wprost do przesiedleń na skutek negatywnych skutków zmian środowiska i nie są dokumentem prawnie wiążącym, tj. nie przewidują żadnych sankcji za niestosowanie się do ich zaleceń. W konsekwencji część badaczy nie uznaje takiego instrumentu ochrony za wystarczający, postulując nieużywanie kryterium transgraniczności do definiowania migracji klimatycznych ${ }^{43}$.

Niezależnie od preferowanego środka ochrony prawnej w zakresie migracji klimatycznych, na poziomie definicyjnym kryterium transgraniczności powin-

${ }^{38}$ Por. M. Prieur, J. Marguénaud, G. Monediaire et al., Draft convention, op. cit.; D. Hodgkinson, T. Burton, H. Anderson, L. Young, The Hour, op. cit.

39 W. Kälin, Conceptualising Climate-Induced Displacement [w:] Climate Change and Displacement. Multidisciplinary Perspectives, ed. J. McAdam, Oxford, Hart 2010, s. 81-103.

40 Zob. J. Hathaway, The Law of Refugee Status, 1991, cyt. za: D. Hodgkinson, T. Burton, H. Anderson, L. Young, The Hour, op. cit.

${ }^{41}$ UN High Commissioner for Refugees (UNHCR), Guiding Principles on Internal Displacement, 1998, ADM 1.1,PRL 12.1, PR00/98/109, https://www.refworld.org/docid/3c3da07f7.html.

42 Ibidem.

${ }^{43}$ Zob. m.in. E. El-Hinnawi, Environmental, op. cit.; N. Myers, J. Kent, Environmental, op. cit.; F. Biermann, I. Boas, Preparing, op. cit.; D. Hodgkinson, T. Burton, H. Anderson, L. Young, The Hour, op. cit. 
no być brane pod uwagę. Sytuacja prawna osób przemieszczających się w ramach własnego państwa zawsze będzie inna niż tych migrujących poza jego granice. Obywatelom przysługuje wiele praw niedostępnych dla pozostałych migrantów klimatycznych, którzy w obecnym stanie prawnym nie mają podstaw do ubiegania się o status uchodźcy lub ochronę międzynarodową. W związku z tym, biorąc pod uwagę kontekst polityczny, w pierwszej kolejności należy podjąć próby uregulowania sytuacji prawnej przesiedlających się poza granice państwa pochodzenia.

\section{Zasadność posługiwania się pojęciem „uchodźca”}

Kolejnym istotnym zagadnieniem jest terminologia używana $\mathrm{w}$ literaturze przedmiotu dla opisania omawianej grupy. Debata na ten temat ogniskuje się wokół jednego problemu - czy posługiwanie się pojęciem „uchodźca” dla określenia osób przemieszczających się ze względu na negatywne zmiany środowiska jest właściwe?

Definicja prawna uchodźcy została zawarta $\mathrm{w}$ konwencji genewskiej ${ }^{44}$. Zgodnie z jej art. 1 uchodźcą jest osoba, która na skutek uzasadnionej obawy przed prześladowaniem z powodu rasy, religii, narodowości, przynależności do określonej grupy społecznej lub z powodu poglądów politycznych przebywa poza granicami państwa, którego jest obywatelem, oraz nie może lub nie chce z powodu tych obaw skorzystać z ochrony tego państwa. Definicja ta wskazuje na dwa podstawowe elementy: a) uzasadnioną obawę przed prześladowaniem ze względu na b) jeden z pięciu wymienionych kryteriów. Kontrowersje związane z mówieniem o „uchodźcach klimatycznych/ środowiskowych” związane są z faktem, że uchodźca jest pojęciem prawnym, z którego wynikają określone przywileje. Brak międzynarodowych uregulowań w zakresie migracji klimatycznych spowodował podział w środowisku naukowym i doprowadził do rozbieżności interpretacyjnych w zakresie możliwości stosowania konwencji genewskiej.

Z jednej strony używanie takiej terminologii mogłoby błędnie sugerować, że osoby te są objęte międzynarodową ochroną prawną gwarantowaną przez konwencję genewską ${ }^{45}$. ONZ stanęła na stanowisku, że definicja uchodźcy nie może być interpretowana rozszerzająco, a dodawanie do niej nowych kryteriów (takich jak np. czynniki środowiskowe) nie ma uzasadnienia na gruncie prawnym i jest praktyką błędną, wprowadzającą zamieszenie interpretacyjne ${ }^{46}$. ONZ w przygotowanym przez siebie podręczniku Zasady i tryb ustalania statusu uchodźcy: zgodnie z Konwencja dotycząca statusu uchodźcy z 1951 r. oraz Pro-

${ }^{44}$ Zob. przypis 17.

45 P. Krajewski, K. Groszkowska, Problematyka, op. cit., s. 149.

${ }^{46}$ UN High Commissioner for Refugees, Climate Change, Natural Disasters and Human Displacement: A UNHCR Perspective, 23 October 2008, https://www.refworld.org/docid/492bb6b92.html [dostęp: 17 września 2019 r.] 
tokołem dodatkowym do niej z 1967 ${ }^{47}$, w paragrafie 39 bezpośrednio instruuje, że ofiary katastrof naturalnych oraz głodu są wyłączone z zakresu zastosowania konwencji genewskiej, wykluczając tym samym możliwość rozszerzenia definicji uchodźcy tak, by objęła omawianą grupę. Zgodnie ze stanowiskiem Wysokiego Komisarza do spraw uchodźców uznawanie zmian klimatu za rodzaj prześladowania i bezpośredni czynnik przesiedleń jest nadużyciem ${ }^{48}$. Tak jak nie sposób zaprzeczyć, że warunki naturalne mogą mieć wpływ na decyzję o migracji, nie ma możliwości przyznania międzynarodowej ochrony prawnej wyłącznie na takiej podstawie ${ }^{49}$. Zdaniem Komisarza rozszerzające interpretowanie konwencji genewskiej mogłoby doprowadzić do podważenia i tym samym rozregulowania istniejącego porządku prawnego, a potencjalne korzyści dla stosunkowo niewielkiej grupy migrantów nie uzasadniłyby wprowadzenia takich zmian w treści konwencji, które wymagałyby ponownego negocjowania całego dokumentu ${ }^{50}$. Otwarte pozostaje pytanie, czy w obliczu istniejącego kryzysu migracyjnego renegocjowanie prawa uchodźczego, zamiast objąć ochroną szerszą grupę migrantów, nie odniosłoby całkowicie odwrotnego skutku.

Drugą często przytaczaną przesłanką przeciwko stosowaniu konwencji genewskiej w omawianym kontekście jest fakt, że jej głównym celem jest ochrona prawna jednostek - które doświadczają prześladowania o charakterze dyskryminującym ze względu na swoją rasę, religię, przekonania polityczne czy przynależność do określonej zbiorowości - nie zaś całych grup społecznych ${ }^{51}$. Negatywne skutki zmian klimatu w sposób porównywalny wpłyną na całą społeczność zamieszkującą dany teren, w związku z czym nie sposób byłoby w takiej sytuacji wykazać czynnika dyskryminującego. Ponadto w tym wypadku sprawcą prześladowania nie jest rząd ich kraju, ale raczej ci przedstawiciele społeczności międzynarodowej, którzy przyczyniają się w największym stopniu do zanieczyszczania środowiska i, tym samym, do zmian klimatu ${ }^{52}$.

Z drugiej strony część badaczy opowiada się za koniecznością zmiany lub reinterpretacji wynikającej z konwencji genewskiej definicji uchodźcy. Głównym argumentem za takim rozwiązaniem jest fakt, że dokument ten zakłada utrwa-

${ }^{47}$ UN High Commissioner for Refugees, Handbook on Procedures and Criteria for Determining Refugee Status under the 1951 Convention and the 1967 Protocol relating to the Status of Refugees, reissued February 2019, HCR/1P/4/ENG/REV. 4.

${ }^{48}$ UN High Commissioner for Refugees, Climate Change, op. cit., s. 9.

${ }^{49}$ Ibidem.

${ }^{50}$ Ibidem.

51 Zob. m.in. P. Warren, Forced migration after Paris COP21: Evaluating the „climate change displacement coordination facility”, „Columbia Law Review” 2016, Vol. 116, No. 8; M. Prieur, J. Marguénaud, G. Monediaire et al., Draft convention, op. cit.; B. Docherty, T. Giannini, Confronting, op cit.

52 J. McAdam, Climate Change, Forced Migration, and International Law, Oxford University Press, 2012. 
lony i ukształtowany precedens prawny ${ }^{53}$, a jej strony dysponują już gotowymi rozwiązaniami prawnymi w swoich systemach krajowych ${ }^{54}$. W debacie na temat migracji klimatycznych, szczególnie w języku potocznym i publicystyce, pojęcie „uchodźca klimatyczny” jest często używane, nawet mimo jego nieprzystawania do międzynarodowego prawa uchodźczego ${ }^{55}$, ze względu na ładunek moralny, jaki się z nim wiąże i możliwość wzmocnienia przekazu ${ }^{56}$.

\section{Podsumowanie}

W debacie międzynarodowej na temat zjawiska migracji klimatycznych brakuje spójnej narracji, zarówno w zakresie definicji osób przemieszczających się, jak i proponowanych środków ochrony prawnej. Trudności w wypracowaniu wspólnego stanowiska wynikają z kilku czynników. Ze względu na złożoność samego zjawiska możliwość wyodrębnienia czynników środowiskowych jako głównej przyczyny, obok motywacji ekonomicznych, społecznych czy politycznych, wzbudza wiele wątpliwości. Różne jest także podejście do określenia cech charakterystycznych migracji, tj. przymusowości, tymczasowości i transgraniczności. Granica między dobrowolnością decyzji o migracji a koniecznością wyjazdu ze względu na niedające możliwości przeżycia warunki środowiska jest trudna do wskazania. Otwarte pozostaje pytanie, czy kryterium przymusowości powinno być w ogóle brane pod uwagę, czyli, innymi słowy, jak szeroki powinien być zakres podmiotowy grupy wymagającej ochrony prawnej. Rozwiązania obejmujące także osoby, które dobrowolnie decydują się na migrację w celu uniknięcia potencjalnych, negatywnych skutków zmian klimatu najprawdopodobniej nie spotkałyby się z dużym poparciem politycznym, szczególnie w czasach nasilonej migracji do krajów wysoko rozwiniętych. Analizując kryterium transgraniczności, w przypadku migracji wewnętrznych wydaje się, że wykorzystywanie prawa międzynarodowego jako środka zaradczego wobec problemu wewnętrznego państw byłoby nieuzasadnioną ingerencją w ich suwerenność. Równie istotna jest także kwestia używanych pojęć i zasadność posługiwania się pojęciem „uchodźca”. W literaturze przedmiotu dominuje pogląd, że określenie „uchodźcy klimatyczni” jest nieprawidłowe, a jego używanie wywołuje zamieszanie prawne ${ }^{57}$. Ponadto rozszerzające interpretowanie pojęcia „uchodź-

53 B. Docherty, T. Giannini, Confronting, op. cit., s. 363.

${ }^{54}$ C. Cournil, The protection of "environmental refugees' in the international law [w:] Migration and Climate Change, ed. E. Piguet, Cambridge University Press, 2012, s. 360.

55 A. Epiney, „Environmental refugees”: aspects of international state responsibility [w:] Migration and Climate Change, ed. E. Piguet, Cambridge University Press, 2012, s. 388.

${ }_{56}$ Zob. przypis 9.

57 Zob. m.in. E. El-Hinnawi, Environmental, op. cit.; N. Myers, J. Kent, Environmental, op. cit.; F. Biermann, I. Boas, Preparing, op. cit.; D. Hodgkinson, T. Burton, H. Anderson, L. Young, The Hour, op. cit.; P. Krajewski, K. Groszkowska, Problematyka, op. cit., s. 149. 
ca" tak, by objęło również migrantów klimatycznych mogłoby doprowadzić do rozregulowania istniejącego systemu i konieczności renegocjowania konwencji genewskiej. Niemniej język publicystyczny, opisując zjawisko zmian klimatu i migracji, posługuje się pojęciem „uchodźców klimatycznych”, dzięki czemu jest ono rozpoznawalne przez szersze grono odbiorców.

Określenie warunków uznania za uchodźcę lub migranta klimatycznego jest również uzależnione od sugerowanego instrumentu prawnego. Dla zwolenników twardego prawa w postaci nowej konwencji międzynarodowej lub dodatkowego protokołu do umów już zawartych kluczowe będzie precyzyjne określenie takich kryteriów, jak rodzaj czynnika środowiskowego, przymusowość czy transgraniczność. Istnieje obawa, że zawężenie proponowanego zakresu ochrony np. tylko do przekraczających granicę państwa lub przesiedlonych tylko ze względu na katastrofy naturalne spotka się z krytyką obrońców praw człowieka jako nieuzasadnione ograniczanie ochrony prawnej i zmniejszanie skali problemu. Wprowadzanie takich kategorycznych podziałów ma mniejsze znaczenie w przypadku zamiaru wykorzystania istniejących mechanizmów prawnych wynikających np. z praw człowieka, prawa humanitarnego czy uchodźczego, jednakże takie rozwiązania mogą okazać się mało skuteczne. Rozwiązania prawne w zakresie migracji klimatycznych i określenie cech charakterystycznych grupy wymagającej ochrony prawnej są związane $\mathrm{z}$ osiągnięciem porozumienia na poziomie międzynarodowym w sprawie wpływu człowieka na zmiany klimatu i konsekwencji tych zmian dla warunków środowiska naturalnego w różnych regionach świata.

\section{Bibliografia}

Biermann F., Boas I., Preparing for w warmer world: towards a global governance system to protect climate refugees, „Global Environmental Politics” 2010, Vol. 10, No. 1, https:// doi.org/10.1162/glep.2010.10.1.60.

Cournil C., The protection of 'environmental refugees' in the international law [w:] Migration and Climate Change, ed. E. Piguet, Cambridge University Press, 2012.

Docherty B., Giannini T., Confronting a Rising Tide: A Proposal for a Convention on Climate Change Refugees, „Harvard Environmental Law Review” 2009, Vol. 2, No 2.

El-Hinnawi E., Environmental Refugees, United Nations Environment Programme, Hertfordshire, 1985.

Epiney A., „Environmental refugees”: aspects of international state responsibility [w:] Migration and Climate Change, ed. E. Piguet Cambridge University Press, 2012.

Ferris E., Bergmann J., Soft law, migration and climate change governance, "Journal of Human Rights and the Environment” 2017, Vol. 8 No. 1, https://doi.org/10.4337/ jhre.2017.01.07.

Gemenne F., How thy became the human face of climate change, Research and policy interactions in the birth of the 'environmental migration' concept [w:] Migration and Climate Change, ed. E. Piguet, Cambridge University Press, 2012. 
Gemenne F., One good reason to speak of climate refugees, „Forced Migration Review” 2015, Vol. 49.

Hodgkinson D., Burton T., Anderson H., Young L., The Hour When The Ship Comes In: A Convention For Persons Displaced By Climate Change, „Monash University Law Review" 2010, Vol. 36, No. 1.

Intergovernmental Panel On Climate Change, Summary for policymakers [w]: Climate Change 2014: Impacts, Adaptation, and Vulnerability. Part A: Global and Sectoral Aspects. Contribution of Working Group II to the Fifth Assessment Report of the Intergovernmental Panel on Climate Change [Field, C.B., V.R. Barros, D.J. Dokken, K.J. Mach, M.D. Mastrandrea, T.E. Bilir, M. Chatterjee, K.L. Ebi, Y.O. Estrada, R.C. Genova, B. Girma, E.S. Kissel, A.N. Levy], Cambridge University Press, 2014.

Intergovernmental Panel on Climate Change, Summary for Policymakers [w]: Climate Change 2007: Impacts, Adaptation and Vulnerability. Contribution of Working Group II to the Fourth Assessment Report of the Intergovernmental Panel on Climate Change, eds. M.L. Parry et al., Cambridge University Press, 2007.

Kälin W., Conceptualising Climate-Induced Displacement [w:] Climate Change and Displacement. Multidisciplinary Perspectives, ed. J. McAdam, Oxford, Hart, 2010.

Krajewski P., Groszkowska K., Problematyka migracji klimatycznych w polityce i prawie międzynarodowym, „Journal of Modern Science” 2018, Vol. 1, No. 36, https://doi. org/10.13166/jms/85114.

Mayer B., Concept of Climate Migration Advocacy and its Prospects, Edward Elgar Publishing, Cheltenham 2016.

McAdam J., Climate Change, Forced Migration, and International Law, Oxford University Press, 2012.

Myers N., Kent J., Environmental Exodus : An Emergent Crisis in the Global Arena, Climate Institute, Washington D.C., 1995.

Opitz Stapleton S., Nadin R., Watson Ch., Kellett J., Climate change, Migration and Displacement: the need for a risk-informed and coherent approach, United Nations Development Programme, 2017.

Prieur M., Marguénaud J., Monediaire G. et al., Draft convention on the international status of environmentally displaced persons, „Revue Européenne de Droit de l'Environnement" 2008, No 4.

Renaud F. i in., Control, Adapt or Flee: How to Face Environmental Migration, Intersections Publication Series of United Nations University Institute for Environment and Human Security, 2007, No 5.

UN High Commissioner for Refugees, Guiding Principles on Internal Displacement, 1998, ADM 1.1,PRL 12.1, PR00/98/109, https://www.refworld.org/docid/3c3da07f7.html.

UN High Commissioner for Refugees, Climate Change, Natural Disasters and Human Displacement: A UNHCR Perspective, 23 October 2008, https://www.refworld.org/ docid/492bb6b92.html. 
UN High Commissioner for Refugees, Handbook on Procedures and Criteria for Determining Refugee Status under the 1951 Convention and the 1967 Protocol relating to the Status of Refugees, reissued February 2019, HCR/1P/4/ENG/REV. 4.

United Nations Department of Economic and Social Affairs, International Migration Report 2015. Highlights, 2016, ST/ESA/SER.A/375.

United Nations General Assembly, Global Compact for Safe, Orderly and Regular Migration, 2019, A/RES/73/195.

United Nations Framework Convention on Climate Change, Slow Onset Events - Technical Paper, 2012, FCCC/TP/2012/7.

United Nations Framework Convention on Climate Change, http://unfccc.int/2860.php.

United Nations High Commissioner for Human Rights, The Slow onset effects of climate change and human rights protection for cross-border migrants, Human Rights Council, 2018, A/HRC/37/CRP.4.

Warren P., Forced migration after Paris COP21: Evaluating the „climate change displacement coordination facility”, „Columbia Law Review” 2016, Vol. 116, No. 8. 